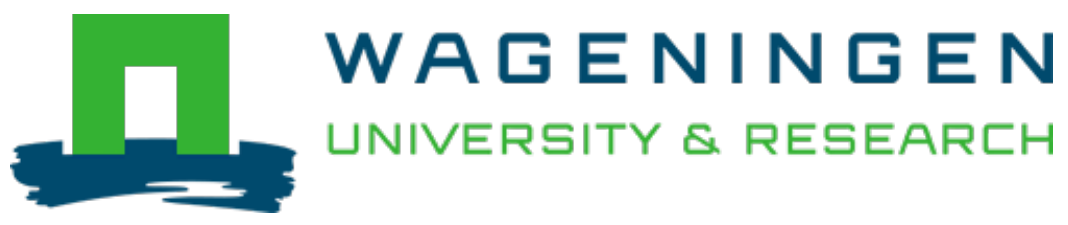

\author{
Soil carbon sequestration in grazing systems: managing expectations \\ Climatic Change \\ Godde, Cécile M.; Boer, Imke J.M.; Ermgassen, Erasmus; Herrero, Mario; Middelaar, Corina E. et al \\ https://doi.org/10.1007/s10584-020-02673-x
}

This article is made publicly available in the institutional repository of Wageningen University and Research, under the terms of article $25 \mathrm{fa}$ of the Dutch Copyright Act, also known as the Amendment Taverne. This has been done with explicit consent by the author.

Article $25 \mathrm{fa}$ states that the author of a short scientific work funded either wholly or partially by Dutch public funds is entitled to make that work publicly available for no consideration following a reasonable period of time after the work was first published, provided that clear reference is made to the source of the first publication of the work.

This publication is distributed under The Association of Universities in the Netherlands (VSNU) 'Article $25 \mathrm{fa}$ implementation' project. In this project research outputs of researchers employed by Dutch Universities that comply with the legal requirements of Article $25 \mathrm{fa}$ of the Dutch Copyright Act are distributed online and free of cost or other barriers in institutional repositories. Research outputs are distributed six months after their first online publication in the original published version and with proper attribution to the source of the original publication.

You are permitted to download and use the publication for personal purposes. All rights remain with the author(s) and / or copyright owner(s) of this work. Any use of the publication or parts of it other than authorised under article $25 \mathrm{fa}$ of the Dutch Copyright act is prohibited. Wageningen University \& Research and the author(s) of this publication shall not be held responsible or liable for any damages resulting from your (re)use of this publication.

For questions regarding the public availability of this article please contact openscience.library@wur.nl 


\title{
Soil carbon sequestration in grazing systems: managing expectations
}

\author{
Cécile M. Godde ${ }^{1,2}$ (D) Imke J. M. de Boer ${ }^{3}$ (D) Erasmus zu Ermgassen ${ }^{4,5}$ (D) \\ Mario Herrero $^{2}$ (D) - Corina E. van Middelaar ${ }^{3}$ - Adrian Muller $^{6,7}$ (D) E Elin Röös ${ }^{8}$ (D) \\ Christian Schader ${ }^{6}$ (D) $\cdot$ Pete Smith $^{9}$ (D) $\cdot$ Hannah H. E. van Zanten ${ }^{3}$ (D) Tara Garnett $^{10}$
}

Received: 19 August 2019 / Accepted: 28 January 2020/Published online: 05 February 2020

(C) Springer Nature B.V. 2020

\begin{abstract}
Grazing systems emit greenhouse gases, which can, under specific agro-ecological conditions, be partly or entirely offset by soil carbon sequestration. However, any sequestration is time-limited, reversible, and at a global level outweighed by emissions from grazing systems. Thus, grazing systems are globally a net contributor to climate change and the time scale of key processes needs to be factored into any mitigation efforts. Failing to do so leads to unrealistic expectations of soil carbon management in grazing systems as a mitigation strategy. Protecting the large carbon stocks in grazing lands is also essential in order to avoid further climate change from additional $\mathrm{CO}_{2}$ release. Despite the time-limited and reversible nature of soil carbon sequestration in grazing lands, sequestration should be promoted in cases where it delivers environmental and agronomic benefits as well as for its potential, particularly on degraded land, to increase the feasibility of limiting global warming to less than 2 or preferably $1.5^{\circ} \mathrm{C}$. Some peer-reviewed sequestration estimates are of a similar order of magnitude to other food systems mitigation options over a 10 20 years period, such as reducing food loss and waste by $15 \%$ or aligning diets with current health related dietary-recommendations. However, caution should be applied to such comparisons since mitigation estimates are associated with large uncertainties and will ultimately depend on the economic cost-benefit relation, feasibility of implementation and time frame considered.
\end{abstract}

Keywords Grasslands · Soil carbon · Climate change $\cdot$ Livestock $\cdot$ Cattle $\cdot$ Greenhouse gases

Electronic supplementary material The online version of this article (https://doi.org/10.1007/s10584-02002673-x) contains supplementary material, which is available to authorized users.

Cécile M. Godde

cecile.godde@csiro.au

Extended author information available on the last page of the article 


\section{Introduction}

The Paris Climate Agreement marks the world's commitment to limit global warming to less than $2{ }^{\circ} \mathrm{C}$ above pre-industrial levels and to pursue efforts to limit the increase to $1.5^{\circ} \mathrm{C}$. While fossil fuel-generated carbon dioxide $\left(\mathrm{CO}_{2}\right)$ from the energy and industry sectors is the main climate change contributor, agriculture and livestock also contribute (Herrero et al. 2016). According to the latest estimates derived from a life cycle assessment approach, the global livestock-related value chain (i.e., from cradle to retail) currently emits about $15 \%$ of anthropogenic greenhouse gas (GHG) emissions. About $30 \%$ or $2.4 \mathrm{Gt} \mathrm{CO}_{2}$-eq/yr (FAO 2018, see Appendix) of these livestock-related GHG emissions come from the planet's 3 billion hectares of grazing systems, defined as livestock production systems found in areas dominated by pastures and rangelands with short growing period ( $<60$ days) or very low human density ( $<$ 20 people per $\mathrm{km}^{2}$ ), in which more than $10 \%$ of the dry matter fed to animals is farm-produced and in which annual average stocking rates are less than 10 livestock units per hectare of agricultural land (FAO 2017a; Robinson et al. 2011; Seré and Steinfeld 1996). These global estimates hide large variations in emissions and emission intensities across regions, systems, and commodities. Concurrently with a raising awareness about livestock-related GHG emissions, soil organic carbon sequestration has attracted significant policy attention as a possible climate change mitigation strategy (e.g., the 4 per 1000 initiative, www.4p1000.org). Grazing management has been suggested as one route to sequester soil carbon but its potential to offset the emissions the animals generate is contested. This essay highlights key factors to consider in the debate about soil carbon sequestration in grazing systems and questions overly optimistic expectations about the potential of grazing systems to contribute to climate change mitigation.

\section{Limits of soil carbon sequestration-context-specific, time-limited, and reversible}

Soil carbon sequestration rates strongly depend on agro-ecological conditions and past and present farming regimes. Meta-analyses find that "improved" grazing systems practices (e.g., adjusted grazing intensity, fire management, legume or grass sowing, pasture fertilization) tend to lead to soil carbon sequestration, by an average of $1.76 \mathrm{t} \mathrm{CO}_{2} / \mathrm{ha} / \mathrm{yr}$ (excluding other GHG emissions, Conant et al. (2017)). This mean gain, however, is derived from a limited number of observations and practices occurring in particular contexts or regions and cannot be extrapolated to the global grazed area since sequestration rates are highly context-dependant (see Appendix for examples of sequestration ranges). Evidence for sequestration benefits of holistic, adaptive, and other variants of rotational grazing is contradictory (Nordborg 2016), although recent studies suggest short-term promising results in some contexts (Stanley et al. 2018). One of the significant challenges to assess the sequestration potential of grazing practices lies in the complexity of the interactions between soils, vegetation, grazing animals, and human interventions which are difficult to capture in the farming management categories usually assessed in the scientific literature.

Any soil carbon sequestration that may arise under specific conditions is time-limited and reversible. Several decades after introducing an improved practice, sequestration rates diminish to zero as soils approach new carbon equilibria (Smith 2014). Sequestered carbon can also rapidly be lost through management change, seasonal or climatic fluctuations (Knapp et al. 2002) or fires (Pellegrini et al. 2018). Grazing land degradation (e.g., wind and water erosion 
of soils, vegetation biomass reductions), while associated with uncertainties in terms of extent and implications for the climate, needs to be halted, since soil carbon can be lost much faster than it can be sequestered (FAO and ITPS (2015), Orr et al. (2017)). Alternative uses of the land, such as forestry, conservation agriculture, or rewilding, can also deliver carbon sequestration and a different mix of non-climate change-related costs and benefits.

\section{Net balance of all GHG emissions and removals to be considered}

The overall contribution of grazing systems to climate change depends on the net balance of all GHG emissions and removals. Methane $\left(\mathrm{CH}_{4}\right)$ emissions from ruminants should not be ignored, nor should potential nitrogen losses from grazing systems, which may be higher under improved pasture (Appendix). Efforts to sequester carbon and reduce $\mathrm{CH}_{4}, \mathrm{CO}_{2}$, and nitrous oxide $\left(\mathrm{N}_{2} \mathrm{O}\right)$ emissions may not always align (van Groenigen et al. 2017).

At the global scale, grazing systems are currently net emitters of GHGs and climate-neutral grazing systems are the exception rather than the norm. Though some non-peer-reviewed studies claim that as much as 12,600-30,240 $\mathrm{Mt} \mathrm{CO}_{2} / \mathrm{yr}$ (Itzkan 2014) or 45,290 $\mathrm{Mt} \mathrm{CO}_{2} / \mathrm{yr}$ (Savory Institute 2013) could be sequestered in grazing systems, estimates in the peerreviewed literature are more modest. According to the latter, global grasslands could potentially, and under still optimistic assumptions, sequester between 37 and $2090 \mathrm{Mt} \mathrm{CO}_{2} / \mathrm{yr}$ depending on the approaches considered (Batjes (2019), Henderson et al. (2015), Smith et al. (2008), see Appendix). Even these estimates are optimistic as sequestration is timelimited and reversible. They also do not capture the many socio-economic barriers to the largescale adoption of grazing best practices, which differ largely among regions, villages, and households (Godde et al. 2018). At the higher end, Batjes (2019)'s biophysical sequestration potential of $2090 \mathrm{Mt} \mathrm{CO} / \mathrm{yr}$ assumes annual carbon increases of 3 to $5 \%$ o with respect to estimates of present soil organic carbon mass (assumption similar to the 4 per 1000 initiative) on all degraded grasslands. This upper estimate is thus based on a proportional annual increase in soil organic carbon to align with the 4per1000 aspirational mitigation target rather than on best estimates for soil carbon gains which, as acknowledged in Batjes (2019), provides a picture that is too optimistic in a context of climate change mitigation. Further, an implicit assumption of the approach is that possible carbon gains will be greatest where soil organic carbon stocks are the largest which may not always be the case since depleted soils have the greatest potential to gain carbon (FAO 2017b). In the same study, sequestration potentials considered as "achievable" are lower and range from 37 to $330 \mathrm{Mt} \mathrm{CO}_{2} / \mathrm{yr}$ depending on the methods and assumptions on total land area subjected to improved management practices.

\section{Changing contribution of grazing systems to the net climate balance}

Changes in the structure and trajectories of animal production systems mean that the contribution of grazing systems to the net climate balance is changing. The expansion of grazing systems has historically driven deforestation and associated $\mathrm{CO}_{2}$ release, but the current global trend towards grazing systems intensification will influence the balance in complex ways (Godde et al. 2018). For example, productivity gains may reduce land pressures and emissions per kilogram of milk and meat produced from grass-fed animals but can be associated with emissions trade-offs such as increases in nitrogen leaching. Higher absolute GHG emissions can also occur where increases in 
animal numbers outweigh mitigation benefits from efficiency improvements. Other productionside mitigation strategies such as the adoption of new technologies that reduce GHG emissions may also influence the net GHGs balance. In addition, changes in environmental factors not directly related to grazing management, such as temperature, precipitation, atmospheric $\mathrm{CO}_{2}$ concentrations, and atmospheric nitrogen deposition, may also affect soil carbon sequestration dynamics (Boone et al. 2018; Fornara and Tilman 2012).

\section{Soil carbon sequestration in the broader context of mitigation efforts}

Soil carbon sequestration potential in grazing systems needs to be placed within the broader context of mitigation efforts (Poore and Nemecek 2018; Rogelj et al. 2018; Springmann et al. 2018; Willett et al. 2019; Wollenberg et al. 2016). Wollenberg et al. (2016) identified a preliminary global target for reducing non- $\mathrm{CO}_{2}$ emissions from agriculture of $\sim 1000 \mathrm{Mt}$ $\mathrm{CO}_{2}$-eq/yr by 2030 to limit warming in 2100 to $2{ }^{\circ} \mathrm{C}$ above pre-industrial levels. Yet, they found that plausible strategies relying on existing practices with non- $\mathrm{CO}_{2}$ emission mitigation co-benefits deliver only $21-40 \%$ of the mitigation target. This large gap indicates the need for more transformative technical and policy options.

Soil carbon sequestration in grazing systems is one strategy, with a global mitigation potential of 37-800 $\mathrm{Mt} \mathrm{CO}_{2} / \mathrm{yr}$ according to studies building on empirical data (economic potentials of 144 and $800 \mathrm{Mt} \mathrm{CO}_{2} / \mathrm{yr}$ in 2030 at US\$20 and US\$100 per t $\mathrm{CO}_{2}$-eq). However, as highlighted above, contrary to non- $\mathrm{CO}_{2}$ mitigation options (Smith et al. 2014), it is time-limited and reversible. Other key options, as identified by Wollenberg et al. (2016), include reducing deforestation due to agriculture, which would mitigate $1710-4310 \mathrm{Mt} \mathrm{CO}_{2}$-eq/yr in 2030 at US\$20 per t $\mathrm{CO}_{2}$-eq according to Carter et al. (2015) and Havlík et al. (2014). Improvements in crop and rice management as well as restoration of degraded croplands (including organic soils) would mitigate 1240 and $2900 \mathrm{Mt}$ $\mathrm{CO}_{2}$-eq/yr in 2030 at US\$20 and US\$100 per $\mathrm{t} \mathrm{CO}_{2}$-eq (Smith et al. 2008). Reducing food loss and waste by $15 \%$ would reduce emissions by $790-2000 \mathrm{Mt} \mathrm{CO}_{2}$-eq/yr in 2030 (Stehfest et al. 2013). Dietary shifts to meet the World Health Organization recommendations (Stehfest et al. 2013) or in response to increases in carbon prices (Havlík et al. 2014) would mitigate $310-1370 \mathrm{Mt} \mathrm{CO}_{2}$-eq/yr in 2030. Targets focused on the livestock supply chain indicate potential reductions of $1770 \mathrm{Mt} \mathrm{CO}_{2}$-eq/yr (Gerber et al. 2013, excluding changes in carbon stocks not involving land-use change).

These mitigation estimates are however strongly influenced by the studies' choice of interventions and methods. They are associated with large uncertainties and will ultimately depend on the economic cost-benefit relation and feasibility of implementing the different strategies.

\section{Conclusion}

In conclusion, grazing systems at an aggregate global level currently emit more GHGs than they sequester. While grazing-induced sequestration should not be ignored as a mitigation strategy and should be promoted where possible by tailored farming strategies in tandem with institutional support (IPCC 2014), its global mitigation potential is lower than often implied. To meet the goals of the Paris Climate Agreement, other mitigation strategies should, therefore, be implemented. 


\section{Future research needs}

Since sustainability encompasses concerns wider than climate change, defining the role of grass-based livestock production within the planet's natural resource capacity and in the context of other environmental, ethical, and societal goals will require a food systems approach that seeks to understand relationships among different and sometimes competing objectives and to harmonize where possible. For example, comparisons between the climatic performance of grazing systems and other production systems were not examined in this essay but merit research. The criticism of sometimes overly optimistic claims on grazing systems' mitigation potential does not challenge the potential sustainability benefits of grazing systems along a number of other indicators, which have not been addressed in this study. A particular focus will need to be placed on ensuring that grazing systems are managed to perform well across several sustainability themes (e.g., food security, livelihoods, animal welfare, disease outbreaks prevention, biodiversity conservation, ecosystems protection). However, further research is needed to understand the integrated impact of grazing systems on these other areas.

Authors' contributions T.G. and C.M.G. conceived and led the project, reviewed the literature, analyzed the data, wrote the paper. I.J.M.B., E.Z.E., M.H., C.E.M., A.M., E.R., C.S., P.S., and H.H.E.Z. conceived the project, reviewed the literature, analyzed the data, and edited the paper.

Funding information The inputs of C.M.G., M.H., and P.S. contribute to the project DEVIL [NE/M021327/1]. The input of P.S. also contributes to the following projects: U-GRASS [NE/M016900/1] and Soils-R-GRREAT [NE/P019455/1]. We thank the Centre of Organic Production and Consumption (EPOK) at the Swedish University of Agricultural Sciences for funding E.R.'s part of the research.

\section{References}

Batjes NH (2019) Technologically achievable soil organic carbon sequestration in world croplands and grasslands. Land Degrad Dev 30:25-32. https://doi.org/10.1002/ldr.3209

Boone RB, Conant RT, Sircely J, Thornton PK, Herrero M (2018) Climate change impacts on selected global rangeland ecosystem services. Glob Chang Biol 24:1382-1393. https://doi.org/10.1111/gcb.13995

Carter S, Herold M, Rufino MC, Neumann K, Kooistra L, Verchot L (2015) Mitigation of agricultural emissions in the tropics: comparing forest land-sparing options at the national level. Biogeosciences 12:4809-4825. https://doi.org/10.5194/bg-12-4809-2015

Conant RT, Cerri CEP, Osborne BB, Paustian K (2017) Grassland management impacts on soil carbon stocks: a new synthesis. Ecol Appl 27:662-668. https://doi.org/10.1002/eap.1473

FAO 2017a Global livestock environmental assessment model. Model Description. Version 2.0. Rome, Italy

FAO (2017b) Soil organic carbon: the hidden potential. Food and Agriculture Organization of the United Nations, Rome

FAO 2018 Global livestock environmental assessment model (GLEAM) [WWW Document]. http://www.fao. org/gleam/results/en/. Accessed 4.24.18

FAO, ITPS 2015 Status of the World's soil resources (SWSR) - main report. Rome, Italy

Fornara DA, Tilman D (2012) Soil carbon sequestration in prairie grasslands increased by chronic nitrogen addition. Ecology 93:2030-2036. https://doi.org/10.1890/12-0292.1

Gerber PJ, Steinfeld H, Henderson B, Mottet A, Opio C, Dijkman J, Falcucci A, Tempio G (2013) Tackling climate change through livestock - a global assessment of emissions and mitigation opportunities. Food and Agriculture Organization of the United Nations (FAO), Rome

Godde C, Garnett T, Thornton P, Ash A, Herrero M (2018) Grazing systems expansion and intensification: drivers, dynamics, and trade-offs. Glob Food Sec 16:93-105. https://doi.org/10.1016/j.gfs.2017.11.003

Havlík P, Valin H, Herrero M, Obersteiner M, Schmid E, Rufino MC, Mosnier A, Thornton PK, Böttcher H, Conant RT, Frank S, Fritz S, Fuss S, Kraxner F, Notenbaert A (2014) Climate change mitigation through livestock system transitions. Proc Natl Acad Sci U S A 111:3709-3714. https://doi.org/10.1073 /pnas.1308044111 
Henderson B, Gerber PJ, Hilinski TE, Falcucci A, Ojima DS, Salvatore M, Conant RT (2015) Greenhouse gas mitigation potential of the world's grazing lands: modeling soil carbon and nitrogen fluxes of mitigation practices. Agric Ecosyst Environ 207:91-100. https://doi.org/10.1016/j.agee.2015.03.029

Herrero, Conant R, Havlik P, Hristov AN, Smith P, Gerber P, Gill M, Butterbach-Bahl K, Henderson B, Valin H, Thornton PK (2016) Greenhouse gas mitigation potentials in the livestock sector. Nat Clim Chang 6:452461. https://doi.org/10.1038/nclimate2925

IPCC (2014) Climate change 2014: mitigation of climate change. Contribution of working group III to the fifth assessment report of the intergovernmental panel on climate change. Cambridge University Press, Cambridge, and New York

Itzkan S 2014 Upside (drawdown) the potential of restorative grazing to mitigate global warming by increasing carbon capture on grasslands. Somerville

Knapp AK, Fay PA, Blair JM, Collins SL, Smith MD, Carlisle JD, Harper CW, Danner BT, Lett MS, McCarron JK (2002) Rainfall variability, carbon cycling, and plant species diversity in a mesic grassland. Prog Am Assoc Adv Sci 298:2202-2205. https://doi.org/10.1126/science.1076347

Nordborg M (2016) Holistic management - a critical review of Allan Savory's grazing method. SLU/EPOK Centre for Organic Food \& Farming \& Chalmers, Uppsala

Orr BJ, Cowie AL, Castillo Sanchez VM, Chasek P, Crossman ND, Erlewein A, Louwagie G, Maron M, Metternicht GI, Minelli S, Tengberg AE, Walter S, Welton S 2017 Scientific conceptual framework for land degradation neutrality. A Report of the Science-Policy Interface. Bonn, Germany

Pellegrini AFA, Ahlström A, Hobbie SE, Reich PB, Nieradzik LP, Staver AC, Scharenbroch BC, Jumpponen A, Anderegg WRL, Randerson JT, Jackson RB (2018) Fire frequency drives decadal changes in soil carbon and nitrogen and ecosystem productivity. Nature 553:194-198. https://doi.org/10.1038/nature24668

Poore J, Nemecek T (2018) Reducing food's environmental impacts through producers and consumers. Science 992(80):987-992

Robinson TP, Thornton PK, Franceschini G, Kruska RL, Chiozza F, Notenbaert A, Cecchi G, Herrero M, Epprecht M, Fritz S, You L, Conchedda G, See L 2011 Global livestock production systems. Rome

Rogelj J, Shindell D, Jiang K, Fifita S, Forster P, Ginzburg V, Handa C, Kheshgi H, Kobayashi S, Kriegler E, Mundaca L, Seferian R, Vilarino MV 2018 Mitigation pathways compatible with $1.5^{\circ} \mathrm{c}$ in the context of sustainable development. Glob. Warm. $1.5^{\circ} \mathrm{C}$. An IPCC Spec. Rep. [...] pp 82

Savory Institute 2013 Restoring the climate through capture and storage of soil carbon through holistic planned grazing

Seré C, Steinfeld H 1996 World livestock production systems: current status, issues and trends (no. 127), Animal Production and Health. Rome

Smith P (2014) Do grasslands act as a perpetual sink for carbon? Glob Chang Biol 20:2708-2711. https://doi. org/10.1111/gcb.12561

Smith P, Martino D, Cai Z, Gwary D, Janzen H, Kumar P, McCarl B, Ogle S, O’Mara F, Rice C, Scholes B, Sirotenko O, Howden M, McAllister T, Pan G, Romanenkov V, Schneider U, Towprayoon S, Wattenbach M, Smith J (2008) Greenhouse gas mitigation in agriculture. Philos Trans R Soc Lond Ser B Biol Sci 363: 789-813. https://doi.org/10.1098/rstb.2007.2184

Smith P, Bustamante M, Ahammad H, Clark H, Dong H, Elsiddig EA, Haberl H, Harper R, House J, Jafari M, Masera O, Mbow C, Ravindranath NH, Rice CW, Robledo Abad C, Romanovskaya A, Sperling F, Tubiello F (2014) Agriculture, Forestry and Other Land Use (AFOLU). In: Edenhofer OR, PichsMadruga R, Sokona Y, Farahani E, Kadner S, Seyboth K, Adler A, Baum I, Brunner S, Eickemeier P, Kriemann B, Savolainen J, Schlömer S, von Stechow C, Zwickel T, Minx JC (eds) Climate Change 2014: Mitigation of climate change. Contribution of Working Group III to the Fifth Assessment Report of the Intergovernmental Panel on Climate Change. Cambridge University Press, Cambridge and New York, pp 811-922. https://doi.org/10.1016/j.phrs.2011.03.002

Springmann M, Clark M, Mason-D’Croz D, Wiebe K, Bodirsky BL, Lassaletta L, de Vries W, Vermeulen SJ, Herrero M, Carlson KM, Jonell M, Troell M, DeClerck F, Gordon LJ, Zurayk R, Scarborough P, Rayner M, Loken B, Fanzo J, Godfray HCJ, Tilman D, Rockström J, Willett W (2018) Options for keeping the food system within environmental limits. Nature 562:519-525. https://doi.org/10.1038 /s41586-018-0594-0

Stanley PL, Rowntree JE, Beede DK, DeLonge MS, Hamm MW (2018) Impacts of soil carbon sequestration on life cycle greenhouse gas emissions in Midwestern USA beef finishing systems. Agric Syst 162:249-258. https://doi.org/10.1016/j.agsy.2018.02.003

Stehfest E, van den Berg M, Woltjer G, Msangi S, Westhoek H (2013) Options to reduce the environmental effects of livestock production - comparison of two economic models. Agric Syst 114:38-53. https://oi. org/10.1016/j.agsy.2012.07.002 
van Groenigen JW, van Kessel C, Hungate BA, Oenema O, Powlson DS, van Groenigen KJ (2017) Sequestering soil organic carbon: a nitrogen dilemma. Environ Sci Technol 51:4738-4739. https://doi.org/10.1021/acs. est.7b01427

Willett W, Rockström J, Loken B, Springmann M, Lang T, Vermeulen S, Garnett T, Tilman D, DeClerck F, Wood A, Jonell M, Clark M, Gordon L, Fanzo J, Hawkes C, Zurayk R, Rivera JA, De Vries W, Sibanda L, Afshin A, Chaudhary A, Herrero M, Agustina R, Branca F, Lartey A, Fan S, Crona B, Fox E, Bignet V, Troell M, Lindahl T, Singh S, Cornell S, Reddy S, Narain S, Nishtar S, Murray C (2019) Food in the Anthropocene: the EAT-Lancet Commission on healthy diets from sustainable food systems. Lancet 6736:3-49. https://doi. org/10.1016/S0140-6736(18)31788-4

Wollenberg E, Richards M, Smith P, Havlík P, Obersteiner M, Tubiello FN, Herold M, Gerber P, Carter S, Reisinger A, van Vuuren DP, Dickie A, Neufeldt H, Sander BO, Wassmann R, Sommer R, Amonette JE, Falcucci A, Herrero M, Opio C, Roman-Cuesta RM, Stehfest E, Westhoek H, Ortiz-Monasterio I, Sapkota T, Rufino MC, Thornton PK, Verchot L, West PC, Soussana JF, Baedeker T, Sadler M, Vermeulen S, Campbell $\mathrm{BM}$ (2016) Reducing emissions from agriculture to meet the $2{ }^{\circ} \mathrm{C}$ target. Glob Chang Biol 22:3859-3864. https://doi.org/10.1111/gcb.13340

Publisher's note Springer Nature remains neutral with regard to jurisdictional claims in published maps and institutional affiliations.

\section{Affiliations}

Cécile M. Godde ${ }^{1,2}$ - Imke J. M. de Boer ${ }^{3}$ • Erasmus zu Ermgassen ${ }^{4,5}$ - Mario Herrero ${ }^{2}$. Corina E. van Middelaar ${ }^{3}$ - Adrian Muller ${ }^{6,7} \cdot$ Elin Röös $^{8} \cdot$ Christian Schader $^{6} \cdot$ Pete Smith $^{9} \cdot$ Hannah H. E. van Zanten ${ }^{3} \cdot$ Tara Garnett $^{10}$

1 Commonwealth Scientific and Industrial Research Organisation, The University of Queensland, St Lucia, Australia

2 Commonwealth Scientific and Industrial Research Organisation, St Lucia, Australia

3 Animal Production Systems group, Wageningen University \& Research, Wageningen, The Netherlands

4 Earth and Life Institute, UCLouvain, Louvain-la-Neuve, Belgium

5 Fonds de la Recherche Scientifique F. R. S.-FNRS, Brussels, Belgium

6 Department of Socioeconomics, Research Institute of Organic Agriculture FiBL, Frick, Switzerland

7 Weather and Climate Risks WCR, Institute of Environmental Decisions IED, Federal Institutes of Technology ETH Zurich, Zurich, Switzerland

8 Department of Energy and Technology and Centre of Organic Production and Consumption (EPOK), Swedish University of Agricultural Sciences, Uppsala, Sweden

9 Institute of Biological and Environmental Sciences, University of Aberdeen, Aberdeen, UK

10 Food Climate Research Network, Environmental Change Institute and the Oxford Martin School, University of Oxford, Oxford, UK 